\title{
BIBLIJNY WYMIAR KAZNODZIEJSTWA W UJĘCIU KSIĘDZA MARIANA RZESZEWSKIEGO (1911-1982)
}

Wśród bogatego dorobku homiletycznego ks. Mariana Rzeszewskiego ${ }^{1}$ wyraźnie zaznacza się problematyka biblijna ${ }^{2}$. Obejmuje ona różnorodne zagadnienia i w zależności od tego, kiedy były one podejmowane, przed Soborem Watykańskim II czy po nim, mają one zróżnicowane rozłożenie akcentów i problemów. Dominują w zasadzie trzy główne

* Ks. dr hab. Tadeusz Lewandowski - kapłan diecezji włocławskiej, prowadzi zajęcia na Wydziale Teologicznym UMK. W 2011 r. wydał książkę pt. Odnowa kaznodziejstwa polskiego w twórczości homiletów wtoctawskich XX wieku. Od teorii wymowy do teologii przepowiadania (rozprawa habilitacyjna).

${ }^{1}$ Ten artykuł jest skróconą wersją opracowania twórczości homiletycznej M. Rzeszewskiego, zawartą w książce: T. Lewandowski, Odnowa kaznodziejstwa polskiego w twórczości homiletów włocławskich XX wieku. Od teorii wymowy kościelnej do teologii przepowiadania, Torun 2011, s. 299-317.

${ }^{2}$ M. Rzeszewski, Pismo Święte w kaznodziejstwie wspótczesnym, w: Konkordancja podręczna Pisma Świętego Nowego Testamentu, red. E. Dąbrowski, Poznań 1955, s. 32-66; tenże, Kaznodziejstwo. Zagadnienia wybrane, Warszawa 1957, s. 51-58; tenże, Katolicki ruch biblijny i kaznodziejstwo, w: Pismo Święte w duszpasterstwie wspótczesnym, red. E. Dąbrowski, Lublin 1958, s. 141-160; tenże, Do czego zobowiązuje nas wymowa Pisma Świętego, AK 300-302 (1959), s. 167-196; tenże, Postuga stowa, Poznań 1967, s. 42-47; tenże, Podstawy ewangelizacji biblijnej, Włocławek 1975, s. 1-25, mps, Biblioteka WSD we Włocławku. 
tematy: Pismo Święte jako żywe słowo Boga, wykorzystanie Pisma Świętego w kaznodziejstwie i hermeneutyka biblijna w kaznodziejstwie.

\section{PISMO ŚWIĘTE ŻYWYM SŁOWEM BOŻYM}

Biblia jest autentycznym słowem Boga, który nieustannie prowadzi dialog z człowiekiem, aby doprowadzić go do nadprzyrodzonego zjednoczenia ze Sobą. W tym dialogu, między Bogiem i człowiekiem, jest Jezus Chrystus, Bóg-Człowiek i moc Ducha Świętego. To On jest głównym jej autorem, dlatego Kościół przyjmuje ze czcią księgi Pisma Świętego spisane przez ludzi, ale pod natchnieniem Ducha. Bóg posłużył się ludźmi jako autorami narzędnymi, zachowując ich wolność i uwarunkowania czasu i miejsca, aby przez ich posługę przekazać swoje słowo. Kościół uznaje i przyjmuje je za autentyczne słowo Boże ${ }^{3}$.

Kościół „traktuje Pismo św. jako uwierzytelnionego posła niebios"4. $\mathrm{Na}$ jego rolę wskazywał sam Chrystus, odnosząc się z wielkim szacunkiem do Biblii i korzystając $z$ niej w pełnieniu swego posłannictwa. Także Jego uczniowie posługiwali się Biblią. Jest on sługą słowa Bożego, co poświadcza cała jego historia.

Jak ciężka to służba, widać z obu dróg dogmatyki biblijnej, ukazanej przez antiocheńską i aleksandryjską szkołę wyjaśniania Pisma św. Wielkość i siłę tej służby ukazują również pisma i kaznodziejstwo Ojców Kościoła zajmujących się otwartym i ukrytym znaczeniem słowa Bożego w Piśmie św. I scholastyka bierze Pismo Święte jako przedmiot teologii. Teologia ta oznaczała spekulatywne przenikanie Pisma Świętego. Stąd np. kaznodziejstwo św. Bernarda jest tak przeniknięte Pismem św. Jest on jako „ostatni Ojciec Kościoła” klasycznym świadkiem średniowiecza na wewnętrzny autorytet Pisma Świętego. Jeszcze w Baroku można zauważyć w teorii i praktyce kaznodziejskiej ten prymat Pisma Świętego. ${ }^{6}$

Objawienie Boże zapisane na kartach Pisma Świętego. jest wyrazem Bożej miłości do człowieka, jest zapisem historii tej miłości, zapisem Bożych interwencji, które prowadzą ku Chrystusowi, w Nim osiągają swe

\footnotetext{
3 Por. tenże, Kaznodziejstwo, s. 28n.; tenże, Katolicki ruch biblijny, s. 144 n.

4 Tenże, Katolicki ruch biblijny, s. 144.

5 Por. tamże, s. 150-151.

6 Tamże.
} 
wypełnienie. Pismo Święte jest więc historią zbawienia, ukazuje tajemnicę więzi Boga z człowiekiem. Przez historię zbawienia Bóg objawia się coraz bardziej w dialogu miłości, który jest wezwaniem do postawy wiary. I choć historia zbawienia zawarta w Biblii

jest naprawdę historyczna, to przekracza historię ludzką. Nie jest tylko zapisem pewnych faktów; jest dynamicznym procesem obejmującym przeszłość, teraźniejszość i przyszłość. Jest to pasjonujące opowiadanie o tym, jak Bóg działa w naszym świecie, udzielając się ludzkości i przyciągając ją do siebie coraz bliżej. Jest to opowiadanie o rozwijającym się dialogu między Bogiem a człowiekiem; dialogu między osobami

Słowo Boże zawarte w Biblii nie uczy historii, lecz ukazuje dzieje naszego zbawienia. W Piśmie Świętym rozwija się tajemnica Chrystusa, czyli plan Bożej miłości do ludzi objawiony w Jezusie Chrystusie. Uwidacznia się w niej jedność historii zbawienia. Stary Testament był kontekstem przyjścia Chrystusa, Nowy mówi, kim On jest. Chrystus jest więc wypełnieniem słów Starego Testamentu, ale nie tylko.

Jeśli Chrystus jest sakramentem Boga, Kościół jest sakramentem Chrystusa i Jego przedłużeniem na ziemi. I w tym Kościele mamy Ducha Bożego mówiącego nam prawdę. Jest to środowisko naszej historii zbawienia, gdzie Bóg działa na nas i w nas i gdzie my odpowiadamy w wierze i miłości ${ }^{8}$.

Odpowiedź w wierze i miłości jest możliwa, ponieważ w Kościele rozbrzmiewa ciągle autentyczne słowo Boże zawarte w Piśmie Świętym, ono jest bowiem źródłem zbawczej wiary i ono wzywa człowieka do odpowiedzi wiary. Pismo Święte jest ciągle dla człowieka słowem Bożym i moca, "Logosem w duchu, podczas gdy Eucharystia daje nam Logos w Prawdzie" ${ }^{\prime \prime}$. Te dwie rzeczywistości przychodzenia Boga - w Piśmie Świętym i łamaniu chleba - są podstawą żywotności Kościoła.

Ksiądz Rzeszewski podkreśla, że dowartościowanie Pisma św. jako żywego słowa Bożego w życiu Kościoła dokonało się dzięki encyklice Piusa XII Divino afflante Spiritu i odnowie biblijnej. Pismo Święte nie jest księgą odległa, ono mówi ciągle do współczesnego człowieka, żądając jego decyzji, chcąc w nas się wypełnić. Jest księgą ludzkości, w której

7 Tenże, Podstawy ewangelizacji, s. 7.

8 Tamże, s. 9.

9 Tenże, Katolicki ruch biblijny, s. 149. Por. także tenże, Kaznodziejstwo, s. 57. 
ciągle na nowo trzeba uczyć się rozeznawania i przyjmowania woli Bożej. Przykładem takiego rozumienia i odczytywania Biblii jest Jezus.

Biblia jest partyturą określonego przez Boga życia Jezusa. Przeczuwamy, że w dalszym ciągu mistycznego życia Jezusa w Kościele i duszach ludzkich życie to będzie nosić rysy wymienione w Piśmie Świętym. Jest to najgłębszy powód, dla którego wszelkie życie chrześcijańskie i jego odrodzenie normuje się Pismem Świętym: jest ono również partyturą życia chrześcijańskiego ${ }^{10}$.

Pismo Święte jest więc bezcennym darem dla Kościoła, a dla kapłanów ten dar oznacza zadanie i posłannictwo. Są oni posłani przez Kościół do urzędowego zwiastowania słowa Bożego. Mają ukazywać, jak tajemnica zbawienia, ukryta w Bogu, odsłaniała się stopniowo aż do wypełnienia w osobie Jezusa Chrystusa. Ich zadaniem jest zaznajomienie wiernych z bogactwem tajemnicy Chrystusa. Żeby mogli wykonać to zadanie, sami muszą zaznajomić się z Pismem Świętym; przez lekturę, medytację, modlitwę muszą przylgnąć do słowa Bożego, napełnić się nim, aby nieść jego zbawcze orędzie współczesnym ludziom ${ }^{11}$.

\section{PISMO ŚWIĘTE W KAZNODZIEJSTWIE}

Pismo Święte jest przede wszystkim źródłem kaznodziejstwa, które należy do historii zbawienia, które jest czynnikiem obecnej fazy zbawienia. Kaznodziejstwo w Kościele jest dalszym ciągiem kaznodziejstwa apostolskiego ${ }^{12}$.

Marian Rzeszewski we wszystkich swych opracowaniach na temat wykorzystania Pisma Świętego w kaznodziejstwie bardzo wyraźnie podkreśla niezastąpioną rolę tekstu biblijnego w przepowiadaniu. Powrót do źródła kaznodziejskiego, jakim jest Biblia, uważa za podstawowy warunek odnowy i ożywienia kaznodziejstwa ${ }^{13}$. Samo jednak rozumienie tego źródła i korzystanie z niego może być bardzo zróżnicowane, co uwidacznia się także w twórczości naszego Autora. Pierwsze publikacje bardziej opierają się na widzeniu Pisma Świętego jako wzoru dla kazno-

\footnotetext{
${ }^{10}$ Tenże, Katolicki ruch biblijny, s. 151.

11 Por. tenże, Postuga stowa, s. 42.

12 Por. tenże, Podstawy ewangelizacji, s. 1.

13 Tenże, Pismo Święte w kaznodziejstwie, s. 34.
} 
dziejstwa, źródła cytatów w kazaniu, natomiast późniejsze koncentrują się na samym orędziu zbawczym zawartym w Biblii, które w kaznodziejstwie ma znaleźć swą aktualizację.

To pierwsze widzenie Biblii wyraźnie dominuje w obszernym opracowaniu Pismo Święte w kaznodziejstwie wspótczesnym $(1955)^{14}$. Zasadniczy akcent jest położony na „wymowę” Biblii, chociaż i tutaj można znaleźć wiele stwierdzeń wskazujących na bardziej źródłowe widzenie roli Pisma Świętego w kaznodziejstwie ${ }^{15}$.

Jeżeli chodzi o widzenie Biblii jako szkoły wyrazu kaznodziejskiego, to ks. Rzeszewski szczególnie podkreśla wzorczość kaznodziejstwa Chrystusa i apostołów. Chrystus jest najdoskonalszym kaznodzieją, „Siewcą Słowa", który siał ziarno słowa Bożego o każdej porze i sposobności ${ }^{16}$. W Nim mówi autentyczny człowiek o oryginalnym umyśle i sercu, a jednocześnie Jego słowo różni się od wszystkich innych, ponieważ jest słowem Boga. Przybliża On prawdę o Królestwie Bożym, odwołując się do porównań ze świata widzialnego. Cechuje Go trafność słowa w działaniu na wolę ludzką. Jest polemistą broniącym integralności prawdy.

Arcykapłańska mowa Chrystusa Pana na Ostatniej Wieczerzy to arcydzieło miłości, jest najbardziej wzruszającym ze wszystkich dzieł wymowy, zakończona arcykapłańską modlitwą, wyszła z Serca przemawiającego jak nikt dotąd ${ }^{17}$.

Chrystus występuje jako Nauczyciel, którego słowo zdumiewa, ponieważ jest to słowo mocy, pełne autorytetu - tak nie mówił nikt z ludzi. W Jego nauczaniu brzmi mocne przekonanie o uniwersalności i trwałości głoszonego słowa. Autorytet Chrystusa jako Nauczyciela nie jest ograniczony ani miejscem, ani czasem, Jego słowo ma bowiem dotrzeć

14 „Ożywienie kaznodziejstwa leży w poważnym, energicznym powrocie do Pisma Św., do jego słowa prostego, żywego, prawdziwego, idącego z duszy do duszy. Chcemy być nowi, interesujący, prawdziwie pożyteczni, korzystajmy z niewyczerpanej skarbnicy Pisma Św. Chcemy być nowi, wzruszający i potężni wobec słuchaczy, to umiejmy do nich mówić mową Pisma Św., Słowem Bożym. Nie może być inaczej". Tamże.

15 Por. tamże, s. 34-35.

16 ,Nie potrzebował ani mównicy, ani synagogi, ani katedry. Studnia w Sychem, brzeg morski, świątynny dziedziniec, krużganki Salomona, gościnny dom obu sióstr Łazarza, plac, przy którym żebrał ślepiec, ulice Jerozolimy... - oto Jego ambona. Nie pisał. Słowo Jego zamknięte w ściśle określoną literę straciłoby na wrażeniu nieskończonej wielkości, czegoś nadnaturalnego, nadnaturalnie tajemniczego". Tamże, s. 36.

17 Tamże, s. 37. 
do wszystkich ludzi, dlatego swój autorytet przekazuje uczniom, aby kontynuowali Jego misję. Choć Jezus zwiastuje nową naukę na podstawie własnego autorytetu, to jednak nawiązuje też do Starego Testamentu, podkreślając, że wypełnia jego słowa i ożywia je „tchnieniem miłości”. Chrystus nie tylko cytuje słowa Starego Testamentu, ale prowadzi do wniknięcia w nie w duchu Pisma Świętego. ${ }^{18}$

Zdaniem ks. Rzeszewskiego sam Chrystus daje przykład, że kazania mają być źródłem poznania i zrozumienia Pisma Świętego. Potwierdzają to apostołowie i ojcowie Kościoła. Apostołowie, zwłaszcza Paweł, odwoływali się bardzo często do Biblii. Kazania ojców Kościoła są w zasadzie praktycznymi komentarzami do Pisma Świętego. Do głosu dochodzą często dzieje biblijne z odniesieniem do współczesnych słuchaczy. W teorii i praktyce św. Augustyna i św. Ambrożego wyraźne jest przekonanie, że kaznodzieja ,jest tłumaczem i sługą Pisma Świętego, powinien służyć mu całym umysłem i całą duszą"19. W kaznodziejskim posługiwaniu Biblii musi dominować fakt miłości Boga do człowieka, bez tego odniesienia bowiem nie zrozumie się jej przesłania ${ }^{20}$.

Znajomość Pisma Świętego i odwoływanie się do niego cechuje postawę największych kaznodziejów w dziejach Kościoła. A. Bossuet podkreślał, że najważniejsze w kaznodziejstwie jest poznanie Pisma Świętego, przejęcie się duchem języka Biblii. Słowa Pisma Świętego nie mogą być tylko ozdobą kazania, ale jego ożywczą siłą ${ }^{21}$. Dla Bourdaloue Pismo św. pełni poczwórną funkcję: jako naczelna zasada i najwyższy autorytet, jako skarbnica przykładów, jako źródło aluzji i porównań oraz jako źródło wzruszeń, uczuć i wstrząsów. Pismo święte jest też podstawą kaznodziejstwa P. Skargi ${ }^{22}$.

O roli Pisma Świętego w kaznodziejstwie przypominały sobory powszechne i synody, a także nauczanie papieży (Leon XIII, Providen-

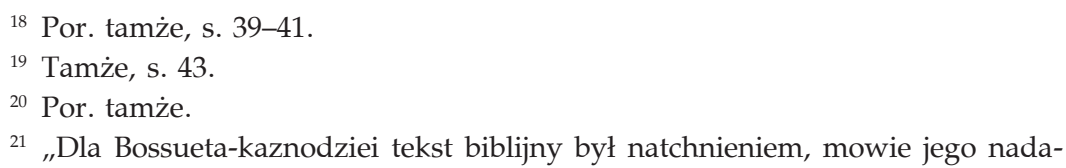
wał przedziwną śmiałość, moc i żar. W kazaniu bierze Pismo Św., aby je wykorzystać retorycznie i rozwinąć, aby przykuć słuchaczy finezyjnymi niespodziankami. W «Rozważaniach» wsłuchuje się w tekst cicho, pokornie i prosto, aż otworzy się przed nim ostatnia głębia... Czytelnik słucha, idzie za Pismem Św., słowo za słowem, zdanie po zdaniu... Nie człowiek tu mówi. Czytamy, rozważamy, zagłębiamy się i wchłaniamy myśli przychodzące naturalnie i prosto. Słuchamy tego, co bierze za serce, nachyla je do Boga i Jezusa Chrystusa". Tamże, s. 45.

22 Por. tamże, s. 45-46. 
tissimus Deus; Benedykt XV, Humani generis; Pius X, Sacris antistitibus), którzy podkreślali, że Pismo św. jest pierwszym źródłem wymowy kościelnej. Przepojone są duchem i językiem Biblii urzędowe księgi Kościoła. To wszystko potwierdza i nawołuje, by duch Pisma św. ożywiał kaznodziejstwo.

Kaznodzieja nigdy nie jest heroldem Boga, jak wtedy, gdy wygłaszając kazanie, opiera się na Biblii. Nigdy słowo jego nie jest bardziej słowem Boga. Pismo Święte dostarcza też kaznodziei nieograniczonego materiału. Tematy szeregują się tu same, czekając na swą kolej. Pismo św. zabezpiecza też kaznodzieję przed nim samym. Wielu kaznodziejów ma swoje "koniki”, wielu wtłacza w nauczanie własne zainteresowania, męcząc słuchaczy. Kaznodzieja zżyty z Pismem Świętym [...] jest zawsze świeży, jak Biblia, która jest nowa każdego ranka. Kaznodziejstwo biblijne ubocznie zachęca słuchaczy do czytania Pisma Świętego ${ }^{23}$.

Aby Pismo św. stało się źródłem kaznodziejstwa, musi najpierw stać się księgą życia dla każdego kaznodziei. Trzeba gruntownie przyswoić sobie biblijne myśli, przejąć się nimi, ich duchem; trzeba nasycić siebie, by tym słowem obdarzyć innych, dostosowując je do aktualnych potrzeb słuchaczy. A ten proces nasycenia siebie słowem Bożym następuje najpierw przez czytanie Biblii. Powinno ono odbywać się ciągle i regularnie aż do przeczytania całości. Przy lekturze trzeba zwrócić uwagę na związek poszczególnych opowiadań biblijnych, które tworzą harmonijną jedność myśli, tworzą teologię biblijną. Lekturze powinno towarzyszyć odpowiednie usposobienie, czyli pokora, czystość, wiara i pilność. Czytanie Pisma Świętego należy traktować jak rodzaj modlitwy ${ }^{24}$.

Ksiądz Rzeszewski uwrażliwia na właściwe cytowanie tekstów Pisma Świętego ${ }^{25}$. Zasady, jakie są stosowane przy cytowaniu różnych tekstów, obowiązują i tutaj, ale trzeba zawsze mieć na uwadze fakt, że

${ }^{23}$ Tamże, s. 47.

${ }^{24}$ Por. tamże, s. 49-51; tenże, Kaznodziejstwo, s. 52.

25 "Cytowanie jest rzeczą twórczą. Jest w nim powszechność myślenia. Klasyczny cytat jest hasłem ludzi mądrych w całym świecie. Powiedzenia ludzi wielkich zawierają często zarodek prawd najgłębszych i najużyteczniejszych. Ale cytowanie wymaga umiejętności. Aby cytować dobrze, trzeba mieć smak, sąd, wykształcenie, ocenę godziwości i zmysł piękna. Sztuka cytowania wymaga więcej delikatności, niż wydaje się tym, którzy widzą w nim tylko podawanie wyimków. Niemniej jest czasem inwencji w cytowaniu niż w tworzeniu myśli. Człowiek inteligentny cytuje mądrze..., napełnia cytat własnym głosem"; tenże, Pismo Święte w kaznodziejstwie, s. 51-52. 
Biblia ma autorytet, z którym nie mogą się mierzyć żadne inne księgi. Na wartość słowa zawartego w Biblii zwraca uwagę Ezechiel:

Synu człowieczy... spożywaj tę księgę i idź przemawiać do synów Izraela; i otworzyłem usta moje i nakarmił mnie ową księgą... i spożyłem ją, a stała się w ustach moich słodką jak miód (Ez 3,1-3).

O jej znaczeniu mówi także św. Paweł:

Wszelkie Pismo przez Boga natchnione jest użyteczne do pouczania, do przekonywania, do napominania, do kształcenia w sprawiedliwości, aby człowiek Boży stał się doskonały i do wszelkiego dobrego dzieła zaprawiony (2 Tym 3,16-17).

Dlatego kaznodzieja powinien „wchłonąć w siebie Pismo Święte”, zarówno jego treść, namaszczenie, jak i bogactwo językowe. Żeby przywrócić znaczenie kaznodziejstwu, należy je przeniknąc Pismem Świętym ${ }^{26}$.

Autor omawia dwa sposoby korzystania z tekstów Pisma Świętego: tekst naczelny i luźne teksty $\mathrm{w}$ toku kazania. Wykorzystywanie tekstu naczelnego zabezpiecza kaznodzieję przed odejściem od tematu. Przypomina mu, że występuje w imieniu Boga, a słuchaczom, że kazanie jest słowem Bożym.

I kazanie powinno rzeczywiście wyrastać z tekstu, wtedy słucha się go jako Bożego poselstwa. Dla kaznodziei tekst jest kotwicą, czasem pasem ratunkowym ratującym przed zatonięciem, jest światłem chroniącym przed zabłąkaniem, jest pobudką, jest gwiazdą dla kaznodziei i słuchaczy ${ }^{27}$.

Może on być stosowany poczwórnie: jako kanwa kazania (wykład tekstu naczelnego), naturalny punkt wyjścia (kaznodzieja zmienia tekst biblijny w jedno treściwe zdanie), jako motto (pewna odpowiedniość między zdaniem tekstu a przedmiotem kazania) i jako konwencja (próba odziania własnych myśli autorytetem Biblii).

Z tekstu naczelnego wyrasta kazanie. Musi on być właściwie wyjaśniony. Pomocą w wyjaśnieniu może być zestawienie tekstów obok

${ }^{26}$ Por. tamże, s. 53.

27 Tamże. Por. tenże, Kaznodziejstwo, s. 54. 
siebie $^{28}$ bądź „łamanie tekstów”29. Wyjaśnianie luźnych, krótkich tekstów jest trudne i wymaga zastosowania kontekstu, by umożliwić słuchaczom śledzenie myśli.

Korzystając z cytatów, zawsze trzeba mieć na względzie szacunek dla Pisma św. Cytować trzeba wiernie i dokładnie, bez przekręcania brzmienia; następnie z umiarem, unikając powodzi tekstów ${ }^{30}$. Ważna jest użyteczność, czyli przydatność dla słuchacza. Cytaty należy dobierać trafnie, ponieważ nie one czynią kazanie biblijnym, lecz ścisły związek kazania z myślą Pisma Świętego. Trzeba zwracać uwagę na urok nowości, ponieważ teksty często powtarzane tracą swą lapidarność dowodową. Korzystając z tekstów biblijnych, należy uwzględnić ich właściwy kontekst. W odpowiednim wyborze tekstów pomaga konkordancja Pisma św. ${ }^{31}$ i dobre komentarze biblijne ${ }^{32}$.

Kazanie biblijne wymaga dojrzałości umysłowej i gruntownego przygotowania kaznodziei. Dotyczy to zarówno znajomości Pisma Świętego, wydobywania z niego zbawczego orędzia, jak i samej szaty słownej kazania.

Więcej słów własnych, świeżych, wyrzeźbionych, niewymuskanych, bo te łatwo ulecą z uszu; więcej słów wyrazistych, znaczących... Nerwowy tryb życia i bystry jego nurt wymaga też zdań krótkich, słowa plastycznego, wypukłego, czasem kanciastego, wielowymiarowego. Takim jest słowo Pisma św. Dlatego na jego glebie spodziewamy się odnowy kaznodziejstwa ${ }^{33}$.

28 „Inteligentne zestawienie takich tekstów jest umysłowo fascynujące dla samego kaznodziei i wzbogacające duchowo dla słuchaczy. Ktokolwiek ma do czynienia z Biblią, jest uderzony zdumiewającą możliwością takich zestawień". Tenże, Pismo Święte w kaznodziejstwie, s. 55.

${ }^{29}$ "Zdarza się czasem, że prawda tekstu ujawnia się najlepiej w jego części. Tak jak leśniczy poznaje wiek drzewa, licząc po ścięciu jego pierścienie, a geolog badając skałę po jej rozbiciu [...], tak samo kaznodzieja musi czasem tekst złamać i podprowadzić słuchaczy do jego przekroju”. Tamże.

30 „Cytowanie nie powinno przytłaczać osobistego wysiłku kaznodziei. Kazanie jest jego poselstwem spełnianym z pomocą Bożą w jego sposób. Przeładowanie tekstami jest z punktu widzenia kaznodziei postojem w pochodzie myślowym, a z punktu widzenia dobrego smaku - jest śmieszne [...]. Odpowiedni cytat w odpowiednim miejscu przygważdża prawdę, ale trzeba być pewnym, że jest on w danym miejscu pożądany; inaczej będzie nadużycie”. Tamże, s. 56.

31 Por. tamże, s. 56-58.

32 Por. tenże, Pismo święte $w$ duszpasterstwie, s. 159.

33 Tenże, Do czego zobowiązuje nas wymowa, s. 195. 
Takie jest zwłaszcza słowo Chrystusa zapisane w Ewangelii. Jego mowa jest mową powszednią; sprawy, które porusza, dotyczą codziennego życia. Prostota Jego słów uderza jednak głębią i mocą. Współczesny słuchacz oczekuje mowy prostej, żywej, porywającej. Słucha chętnie tego,

to mówi rzeczy interesujące i mówi je dobrze. A więc kto podaje temat konkretnie, wyobrażeniowo i podaje go z zapałem, jasno i bez monotonii. Kaznodzieja powinien pamiętać, że kazanie stanowi przygodę w życiu słuchaczy, jeśli do serca ich rzutuje jakiś promień miłości wypełniającej Serce Boże. Miłość ta wyziera z kart Pisma św. ${ }^{34}$

\section{HERMENEUTYKA BIBLIJNA W KAZNODZIEJSTWIE}

Ksiądz Rzeszewski w swych rozważaniach na temat wykorzystania $\mathrm{w}$ kaznodziejstwie zasad hermeneutyki biblijnej wychodzi od podstawowych dokumentów - encykliki Piusa XII Divino afflante Spiritu oraz Instrukcji Komisji Biblijnej w sprawie historyczności Ewangelii (1964). $\mathrm{W}$ świetle przedstawionych tam zasad literackich i teologicznych, pozwalających odkryć autentyczne przesłanie tekstu biblijnego, będącego podstawą kazania biblijnego, stwierdza, że aby zrozumieć słowo Boże, należy najpierw poznać ducha, w jakim tekst powstał.

Trzeba się cofnąć do starożytnego Bliskiego Wschodu - do jego sposobów życia, myślenia, wyrażania się, włącznie z wzorami myśli i wyobraźni - tak żeby słyszeć słowo Boże padające w czasie swego powstania. Bo słowo to nie jest oderwane; zwracało się zawsze do aktualnego adresata, tak że jeśli tego niezmiennego słowa nie bierze się w kontekście czasu i miejsca, to nie pozna się nigdy w pełni jego bogactwa ${ }^{35}$.

Biblia, będąc księgą natchnioną, pochodzącą od Boga, jest jednocześnie księgą wspólnoty, człowieka. Bóg uszanował człowieka, dając mu zdolność wyrażania myśli Bożej na sposób ludzki, stąd treść ksiąg świętych jest odbiciem środowiska, w którym rosły. Stary Testament jest odbiciem epoki w treści i stylu. Jego materiał historyczny jest opowie-

${ }^{34}$ Tamże. Ks. Rzeszewski, mówiąc o wymowie Pisma Świętego, o stylu w Piśmie Świętym, podkreśla, że przekłady Biblii powinny ten styl i wymowę także zachować. Por. tamże, s. 168.

${ }^{35}$ Tenże, Podstawy ewangelizacji, s. 41. 
dziany w sposób właściwy ówczesnemu opowiadaniu historii. Prawda jest przekazywana przez opowiadanie, przypowieść, alegorię, midrasz, ponieważ taki był sposób myślenia Izraelitów i tak wyrażał się on w pisarstwie. Tak więc słowo Boże w Piśmie św. jest naprawdę także słowem ludzkim ${ }^{36}$.

Podobnie trzeba widzieć też Nowy Testament. Jest on literaturą, wyrastającą z ówczesnych ludzkich okoliczności, i efektem najpierw przekazu ustnego, trwającego około trzydziestu lat. Ewangelie są dziełami nie tylko Mateusza, Marka, Łukasza i Jana, ale także dziełem wspólnoty chrześcijańskiej, w której działał Duch Święty. W tekstach Nowego Testamentu występują różne formy literackie: opowiadanie, opowiadanie konfliktowe, opis liturgiczny, wskazania etyczne, midrasz. Tak więc Pismo Święte jest żywym słowem Bożym rozbrzmiewającym w słowie ludzkim ${ }^{37}$. Skoro Biblia podaje słowo Boga w słowach człowieka, nie można go w pełni zrozumieć bez odczytania tego, co chce powiedzieć człowiek. Podstawą odczytania tekstu Pisma św. jest więc odkrycie gatunku literackiego, jakiego użył autor biblijny.

W odkryciu właściwego sensu tekstu biblijnego zasadniczą rolę odgrywa także całościowe spojrzenie na Stary i Nowy Testament, jest to przecież mowa tego samego Boga. Żeby zrozumieć Stary Testament, trzeba go odczytywać w świetle Nowego.

Pewne wydarzenia, rzeczy i osoby Bóg uczynił po to, żeby były zarysem lub typem wydarzeń, rzeczy i osób w przyszłości. Są cieniami przyszłych rzeczywistości. Zrozumienie tych typów rozjaśnia się nam w liturgii i w Nowym Testamencie. „Bo prawo ma tylko cień dóbr przyszłych, a nie dokładny obraz rzeczy” (Hbr 10,1). Adam, Mojżesz i Dawid są typami lub zapowiedzią nowego Adama, nowego Mojżesza, nowego Dawida. Królestwo, Świątynia, Pascha, krew przymierza, kapłaństwo Izraela, samo przymierze, były w Opatrzności Bożej tylko cieniami lub zapowiedzią nowego Królestwa, nowej Świątyni, nowego Przejścia, Krwi, nowego przymierza, nowego kapłaństwa... Objawia się ta sama tajemnica Bożej miłości, ale objawia się stopniowo w czasie ${ }^{38}$.

Kluczem interpretacyjnym Biblii jest więc jedność historii zbawienia. Historia otrzymuje znaczenie przez Izrael i chrześcijaństwo. Przeszłe

\footnotetext{
${ }^{36}$ Por. tamże, s. $42-47$.

37 Por. tamże, s. 61-71.

38 Tamże, s. 14.
} 
wydarzenia Starego Testamentu mają znaczenie dla Nowego, to już w „łonie Izraela Bóg kształtował swój Kościół. Dzieje Izraela są naszymi dziejami"39. Te wzajemne związki między Bożą przeszłością i przyszłymi objawieniami nazywa się typologia, przy czym zapowiedziana rzeczywistość przekracza zawsze oczekiwania wcześniejszego obrazu ${ }^{40}$.

Rzeszewski, prezentując te treści związane z wykorzystaniem zasad literackich i teologicznych w interpretacji tekstów biblijnych, wypracowanych przez hermeneutykę biblijną, podejmuje także zagadnienie tzw. nowej hermeneutyki. Wyjaśnia różnice między tradycyjną i nową hermeneutyką. Tradycyjna zajmuje się krytyką tekstu, zagadnieniami filologicznymi, tłem literatury biblijnej, a więc świeckim, duchowym i kulturowym środowiskiem Biblii, jej obudową archeologiczną, wpływami religijno-historycznymi, autorami ksiąg, ich osobowością, mentalnością, używanymi przez nich formami literackimi w celu wyjaśnienia tekstu. „Nowa" wchodzi głębiej i rozszerza pojęcie hermeneutyki.

Zadaniem hermeneutyki nie jest już usunięcie tylko przeszkód i trudności przy wyjaśnianiu tekstu, lecz raczej w ogóle analiza procesu rozumienia. Trzeba pytać: Jak podchodzę dziś do tekstu, mającego bądź co bądź dwa tysiące lat, do tekstu noszącego szatę dawno zapomnianego czasu? Jak mogę taki tekst nie tylko wyjaśnić, tzn. ustalić w sensie badania krytyczno-historycznego, co autor miał na myśli wtedy, w swoim czasie, kulturze, języku, sytuacji, sposobie myślenia i mówienia, ale jak ten tekst staje się dla mnie dziś wydarzeniem spotykającym mnie w moim życiu i określającym je? Jako człowiek wieku 20-go nie mogę po prostu przywdziać skóry człowieka sprzed dwóch tysięcy lat; i tego wcale nie chcę! Ale wyjaśnienie Pisma św. ma wydarzeniu słowa Bożego, które stało się

39 Tamże, s. 14-15.

40 "Żydowska Pascha, wspominająca i ożywiająca przymierze Synaju, ustąpiła nowej Passze i nowemu przymierzu, przypieczętowanemu Krwią Chrystusa. [...] Jak przymierze Synaju było ratyfikowane w Krwi, tak nowe przymierze będzie przypieczętowane w Krwi Baranka. [...] Przymierze Izraela było niewolą, gdy przymierze Chrystusa jest przymierzem wolności $(\mathrm{Gal} 4,24)$. Nowe przymierze jest przymierzem życiodajnego Ducha... Autor listu do Hebrajczyków porównuje i kontrastuje dwa przymierza. Jest to teologia przymierza i teologia historii... Przymierze Chrystusa jest wyższe od przymierza Abrahama, Mojżesza, Jozuego według wyższości kapłaństwa Chrystusa. Przymierza ich wiązały na krótki okres; przymierze Chrystusa przetrwa... Transcendencja przymierza Chrystusa wypływa z wiecznego odkupienia urzeczywistnianego przez Jego krew (Hbr $9,12)$. W ten sposób porównuje się judaizm z chrześcijaństwem. Tylko chrześcijaństwo jest wieczne i życiodajne, bo ono tylko ma wieczne przymierze, wieczną ofiarę, wieczne kapłaństwo i wieczne prawo miłości". Tamże, s. 15-18. 
tekstem, mową, wielu słowami, pozwolić stać się znów wydarzeniem napełnionym duchem, inaczej dawałoby tylko ciekawe objaśnienie, ale chybiłoby co do swego właściwego celu. Wyjaśniony tekst musi być dla mnie tekstem obdarzającym ${ }^{41}$.

Nie wystarczy więc poznać tło tekstu, wyjaśnić go, trzeba go zrozumieć. Nie jest to jednak proste, ponieważ odległość czasowa między teraźniejszością a pisarzami ksiąg biblijnych stwarza pewną obcość, rośnie różnica duchowa, a z nią trudność porozumienia, potrzeba więc poszukiwania „pomostu” pozwalającego współczesnemu odbiorcy słowa Bożego odczuć, że słowo zapisane „wczoraj” ma „dziś” dla niego wymiar zbawczy i egzystencjalny.

Ksiądz Rzeszewski, chcąc przybliżyć ważność, a jednocześnie złożoność tego zagadnienia, prezentuje i poddaje krytycznej ocenie dwie skrajne postawy: stanowisko K. Bartha i R. Bultmanna. Pierwszy wychodzi w swych rozważaniach "od góry”, a więc koncentruje się na tym, co stoi za słowami, co jest właściwie niewyrażalne, a jednak ma to być ciągle na nowo wypowiadane, Biblia jest bowiem świadectwem o objawieniu Bożym w słowie ludzkim. Barth, w swoim dogmatycznym pojęciu „słowa Bożego", gubi w jakiś sposób rzeczywistość ludzka, pomija „uczestnictwo egzystencjalne” podmiotu, który ciągle na nowo odbiera Boże objawienie ${ }^{42}$.

Bultmann obiera drogę ,z dołu”, od człowieka.

Jego rozważania wyznacza pytanie o sposób mówienia N. Testamentu. Jest on dlań mitologiczny; nie znaczy to, że zajmuje się bajkami; przez mit rozumie Bultmann taki sposób przedstawiania, „w którym tamten świat zjawia się jako ten, w którym np. zaświatowość Boga jest pomyślana jako dalekość przestrzenna. W czasie biblijnym pozostawała prawie w każdym ludzkim wydarzeniu jakaś niewiadoma, która wyjaśniała się przez bezpośrednie działanie Boga, przez Jego moc zaświatową". [...] Mitologiczny sposób mówienia jest więc określony obrazem świata, ale to znaczy, że w istocie mitu wskazuje się, ,jak sam człowiek rozumie siebie w swym świecie", wtedy uwarunkowany wertykalnie przez Boga, a dziś określany przez technikę i naukę. Gdy więc sam mit wyraża własne rozumienie człowieka w swym świecie, to już w nim samym jest kryterium „przetłumaczenia”, tzn. demityzacji: trzeba go wyjaśniać właśnie antropologicznie, egzystencjalnie. Odnosi się to do każdego

\footnotetext{
${ }^{41}$ Tamże, s. 1-2.

${ }^{42}$ Por. tamże, s. 3-5.
} 
tekstu, który jest związany z innym niż nowoczesny obraz świata. Gdy N. Testament w swym mitologicznym sposobie mówienia wyraża własne rozumienie się człowieka, to właśnie jako nowe rozumienie się przez Chrystusa. Chodzi o urzeczywistnienie tego nowego rozumienia siebie także dziś w ramach naszego obrazu świata. Pomost między świadectwami starożytnymi a naszym rozumieniem udaje się wtedy tylko przez egzystencjalne wyjaśnianie Pisma św. ${ }^{43}$

To egzystencjalne wyjaśnienie tekstu biblijnego zakłada „uprzednie zrozumienie omawianej rzeczy”, czyli trzeba mieć uprzednie pojęcie o Bogu, przynajmniej pytania o Boga, które mają odniesienie także do ludzkiego losu. Dopiero wtedy można zrozumieć tekst, "gdy moje pytania i odpowiedzi znajdą się w tekście, gdy zrozumiem siebie w tekście i przez tekst"44. To "spotkanie historyczne” z Pismem Świętym powoduje konieczność ciągłego określania swego życia i dokonywania wyborów, podejmowania konkretnych decyzji. Ostatecznie więc wyjaśnienie egzystencjalne prowadzi do budzenia wiary i jej przekazywania w wielorakich uwarunkowaniach ludzkiego życia. W ten sposób wypowiedziane kiedyś słowo, wypowiedziane w szczególnej sytuacji, trzeba zrozumieć na nowo. Zdaniem ks. Rzeszewskiego należy szukać syntezy między tymi „,biegunowymi” ujęciami ${ }^{45}$.

Opierając się na różnych stanowiskach wyrażanych w „nowej hermeneutyce", zajmującej się zagadnieniem rozumienia tekstów w ogóle, a Pisma św. w szczególności, ks. Rzeszewski podsumowuje dotychczasowe wyniki w tej dziedzinie. Podkreśla, że metoda historyczno-krytyczna w nowszych badaniach hermeneutycznych jest potrzebna, spełnia bowiem funkcję wstępną. Należycie rozumiana demityzacja, polegająca na oddzieleniu od wyobrażeń starożytnego obrazu świata, nieodpowiadających już dzisiejszemu myśleniu, jest uprawniona i konieczna. Trzeba pamiętać, że kto chce wyjaśniać Pismo Święte, musi rozumieć rzeczywistość w niej wyrażoną. Skoro człowiek w swej strukturze historycznej jest trwale otwarty na rozumienie w spotkaniu, to nie można mówić o ostatecznym zamknięciu wyjaśnienia. Tłumaczenie słowa Bożego jest zawsze formą

${ }^{43}$ Tamże, s. 5-6.

${ }^{44}$ Tamże, s. 8.

${ }^{45}$ Por. tamże, s. 10-11. M. Rzeszewski przedstawia nie tylko stanowiska Bartha i Bultmanna. Prezentuje także poglądy teologów stawiających w centrum rozważań pojęcie mowy: E. Fuchsa (zjawisko mowy), G. Ebelinga (wydarzenie słowa) i H. Gadamera (zjawisko przekazywania). Tamże, s. 12-16. 
spotkania z wydarzeniem zbawczym, ciągle ma miejsce "dialog zbawczy" - współdziałanie pytania ludzkiego, słowa Bożego i odpowiedzi człowieka. Ostatecznie prawdziwe rozumienie Pisma św. dokonuje się w łączności z działaniem Ducha Świętego, ma więc znamię charyzmatu. Tym samym

kazanie i katecheza nie może więc być głównie przekazem wiedzy historycznej, a także tylko krytyczno-historycznej, lecz odpowiedzią na otwarte w każdym człowieku pytanie o Boga w Jego wielorakiej rzeczywistości, odpowiedzią czynną w Duchu Świętym, ku oświeceniu życia ludzkiego, "wydarzeniem mowy” ku zbawczemu urzeczywistnianiu prawdziwego chrześcijaństwa ${ }^{46}$.

Stosowanie zasad hermeneutyki biblijnej w kaznodziejstwie ma pomóc w głoszeniu autentycznego słowa Boga. Bóg objawiający się człowiekowi na kartach Pisma Świętego ciągle chce mówić do współczesnego człowieka i temu dialogowi zbawczemu ma służyć kaznodziejstwo. Tylko autentyczne słowo Boże rodzi prawdziwą wiarę, tylko wtedy realizują się słowa Konstytucji dogmatycznej II Soboru Watykańskiego o Objawieniu Bożym, że „Bogu objawiającemu należy się posłuszeństwo wiary” (n. 5).

Objawienie, dochodzące do głosu w Piśmie Świętym, musi się więc wypełnić $\mathrm{w}$ przeżytej wierze, $\mathrm{w}$ życiu wiernych. [...] Wiara jest pełnym stanowiskiem człowieka wobec udzielającego się Boga [...], pełnym ludzkim poddaniem się, „,oddaniem się Bogu całego człowieka na własność". Wierzący nie tylko przyjmuje prawdy objawione, gdy objawiający się Bóg i Jego objawienie pozostaje $\mathrm{w}$ dalekiej przeszłości, ale spotyka on tu i dziś na nowo Boga w aktualizacji Pisma św., w fakcie udzielania się Boga ${ }^{47}$.

Marian Rzeszewski poświęcił wiele miejsca rozważaniom na temat hermeneutyki biblijnej, ponieważ widział ścisłą więź między kaznodziejstwem a egzegezą. Zadaniem kaznodziei jest „łamanie chleba słowa Bożego" współczesnemu człowiekowi, czyli głoszenie i dostosowanie do niego orędzia biblijnego.

Jest jedno Słowo Boga - Jezus Chrystus, Syn Boga. Przez to właśnie Słowo znamy Boga jako miłosiernego i odkupującego Pana. Znamy to Bo-

\footnotetext{
46 Tamże, s. 18

47 Tamże.
} 
skie Słowo poprzez świadectwo dane Mu przez proroków i apostołów, dane wpierw przez ich słowa mówione, a potem utrwalone w Piśmie św. To biblijne świadectwo o Słowie wiecznym jest jedynym punktem wyjścia do kaznodziejstwa. Nie może być kazania chrześcijańskiego bez wyjaśnienia objawionego Słowa Bożego ${ }^{48}$.

Kaznodziejstwo potrzebuje zatem egzegezy katolickiej jako niezbędnego narzędzia do odkrycia autentycznego słowa Boga. To właśnie egzegeta, stosując wypracowane zasady literackie i teologiczne, jak kontekst historyczny, właściwości językowe, formy myślowe i literackie pisarza, jedność Pisma Świętego Starego i Nowego Testamentu, natchniony charakter ksiąg biblijnych, potrafi umieścić dany tekst we właściwym miejscu w rozwijającym się procesie historii zbawienia i odkryć pełne znaczenie tekstu, czyli znaczenie zamierzone przez Boga ${ }^{49}$.

Egzegeta, stosując krytykę tekstu, krytykę historyczną i literacką, a więc korzystając z aparatu naukowego, przygotowuje kaznodziei dostęp do autentycznego słowa Bożego ${ }^{50}$. Tam, gdzie on kończy swoją naukową pracę, rozpoczyna kaznodzieja - wyjaśnia Pismo św., dokonując jego aktualizacji.

Słowo Boga wyrażone w Piśmie Świętym jest często w szacie metafor, niemających znaczenia i barwy dla zachodniego umysłu wieku dwudziestego. Kaznodzieja uczy się od egzegety dokładnego znaczenia języka biblijnego, ale musi go przełożyć na język znaczący i poruszający współczesnego słuchacza. Choć kaznodziejstwo jest formalnie wyjaśnieniem słowa Bożego, to nie jest tylko wyjaśnieniem. Wyjaśnienie samo w sobie nie jest kaznodziejstwem. Kaznodzieja uczy, ale nie tylko uczy. Uczestniczy i kontynuuje profetyczną funkcję Chrystusa. Przez kaznodzieję Chrystus mówi do słuchaczy, udzielając się, prosząc i wywołując odpowiedź. [...] Ufny w Bożą pomoc, kaznodzieja ma wyjaśniać, zachęcać i wywoływać odpowiedź wiary, nadziei i miłości. Będzie dopiero wtedy rozpalał wyobraźnię słuchaczy, poruszał ich serce i wolę, gdy zna orędzie Pisma św. i wypowiada je słowem znaczącym i barwnym ${ }^{51}$.

48 Tamże, s. 3.

49 Por. tamże; tenże, Postuga stowa, s. 45; tenże, Katolicki ruch biblijny, s. 156-159; tenże, Kaznodziejstwo, s. 48.

${ }^{50}$ Ks. Rzeszewski raczej nie widzi kaznodziei w roli egzegety. Sugeruje, by kaznodzieja korzystał z gotowych komentarzy przygotowanych przez egzegetów.

51 Tenże, Podstawy ewangelizacji biblijnej, s. 5. 
Kaznodzieja jest otwarty na słowo Boga, ale to słowo ma przekazać określonemu audytorium, czyli musi znać swoich słuchaczy i uwzględniać ich potrzeby oraz kontekst liturgiczny, w jakim dokonuje się przekaz słowa ${ }^{52}$.

Ksiądz Rzeszewski daje kaznodziejom wiele praktycznych wskazań dotyczących interpretacji zarówno tekstów Starego, jak i Nowego Testamentu. Zasadniczą sprawą jest widzenie całościowe Pisma Świętego. Stary Testament należy traktować jako zapowiedź, Nowy jako wypełnienie. Przydatnym sposobem tłumaczenia tekstów Starego i Nowego Testamentu jest tłumaczenie typiczne ${ }^{53}$.

Jeżeli chodzi o teksty Nowego Testamentu, to trzeba widzieć założenia teologiczne autorów poszczególnych ksiąg, poszczególne wydarzenia widzieć w kontekście, szukać miejsc paralelnych w Ewangeliach ${ }^{54}$.

Kończąc tę prezentację poglądów ks. Mariana Rzeszewskiego, należy podkreślić przemianę, jaką przeszedł on w pojmowaniu roli Pisma Świętego w kaznodziejstwie. W bogatej literaturze powstałej na przestrzeni trzydziestu lat zaznacza się wyraźne przejście od traktowania Biblii jako źródła przykładów, wzoru stylu kaznodziejskiego, bogactwa cytatów do źródła autentycznego słowa Bożego, które trzeba odczytać, opierając się na zasadach literackich i teologicznych, oraz zaktualizować je w każdorazowej sytuacji, by budziło wiarę i niosło zbawienie. Tej problematyce jest poświęcona obszerna publikacja ks. Rzeszewskiego, przygotowana do druku, ale niewydana - Podstawy ewangelizacji biblijnej. Odzwierciedla ona to wszystko, co w ostatnich latach dominowało w kwestii odczytania tekstów biblijnych i ich interpretacji w życiu Kościoła. Mówi o kształtowaniu się tekstu biblijnego, o roli słowa Bożego w powstaniu ludu Starego i Nowego Przymierza, o specyfice zapisanego w Piśmie św. słowa Bożego i roli hermeneutyki biblijnej w odkrywaniu jego właściwego przesłania oraz podaje zasady aktualizacji słowa Bożego w przekazie kaznodziejskim ${ }^{55}$.

52 Por. tamże, s. 7-8.

${ }^{53}$ Tamże, s. 8. Por. tenże, Postuga stowa, s. 45.

${ }_{54}$ Por. tenże, Postuga stowa, s. 45-46.

${ }_{55}$ Por. tenże, Pismo Święte w kaznodziejstwie, s. 32-66; tenże, Kaznodziejstwo, s. 51-58; tenże, Katolicki ruch biblijny, s. 141-160; tenże, Do czego zobowiązuje nas wymowa Pisma Świętego, s. 167-196; tenże, Postuga stowa, s. 42-47; tenże, Podstawy ewangelizacji biblijnej, s. 1-25. 


\section{THE BIBLE PREACHING DIMENSION THE PRIEST MARIAN RZESZEWSKI APPROACH (1911-1982)}

\section{SUMMARY}

The Bible issues are clearly pointed out among the rich homiletics achievements of the priest Rzeszewski, a longlife professor of homiletics at the Higher Theological Seminary in Włocławek. The issues cover a variety of topics and, depending on when they were undertaken, before or after the Second Vatican Council, they have varied emphases and concerns. Basically, three main topics dominate: Holy Bible as a living word of God, the use of the Holy Bible in preaching and the Bible hermeneutics used in preaching.

The analysis of the literature created for over thirty years can observe the clear transition from treating the Bible as a source of examples, the model of the preaching style, plenty of quotations, to the source of authentic word of God, that one needs to read, relying on the literary and theological principles and one needs to update it in any situation so that it awakens the faith and brings salvation. The author dedicated an extensive publication, which was prepared for printing, but which was never released: Basics of the biblical evangelization to these issues. It reflects it all which dominated the reading of biblical texts in recent years and their interpretation in the Church life. It says about the formation of the biblical text, the role of the word of God in creation of the people of the Old and New Testaments, the specificity of the word of God recorded in the Bible and the role of the biblical hermeneutics in discovering its proper message and it also gives the rules for updating the word of God in the homiletic message. In this way the priest Rzeszewski is a part of the latest trend of the proper use of the Bible in preaching. 